\section{Pengaruh Elektroda Pengelasan Pada Baja AISI 1045 Dan SS 202 Terhadap Struktur Mikro Dan Kekuatan Tarik}

\section{Effects of Welding Electrodes on AISI 1045 and SS 202 on the Micro Structure and Tensile Strength}

\author{
Yoyok Winardi' ${ }^{1}$, Fadelan' ${ }^{1}$, Munaji ${ }^{1}{ }^{1}$ Wisnu Nurandika Krisdiantoro ${ }^{1}$ \\ ${ }^{1}$ Teknik Mesin Universitas Muhammadiyah Ponorogo, Ponorogo, Indonesia \\ yoyok@umpo.ac.id 1 , fadelan@umpo.ac.id ${ }^{2}$, munaji@umpo.ac.id ${ }^{3}$, \\ $\underline{\text { Wisnuandika22@gmail.co.id }}{ }^{4}$
}

\begin{abstract}
Abstrak
Pengelasan logam adalah suatu proses pengelasan yang dilakukan pada dua jenis atau paduan logam yang berbeda. Pengelasan logam beda jenis banyak dipakai di berbagai industri, misalnya pembangkit listrik, industri transportasi, kontruksi sipil, dan lain-lain. Baja merupakan material yang banyak digunakan untuk kontruksi. Aplikasinya banyak disambung dengan logam lain. Penyambungannya dilakukan dengan pengelasan. Dalam penggabungan dua logam yang berbeda permasalahan yang sering timbul dalam pengelasan antara lain perbedaan titik lebur, koefisien muai, sifat fisis dan mekanis. Oleh karena itu dengan pemilihan elektroda pengelasan yang tepat akan menghasilkan sambungan yang baik. Penelitian ini bertujuan untuk mengetahui pengaruh jenis elektroda pada baja AISI 1045 dan SS202 terhadap struktur mikro dan kekuatan tarik. Elektroda yang digunakan pada penelitian ini adalah jenis E 6013 dan E 7018. Metode pengelasan menggunakan las SMAW. Struktur mikro dikarakterisasi menggunakan mikroskop optik. Kekuatan mekanik diuji menggunakan mesin uji tarik. Hasil pengamatan struktur mikro pada masing-masing spesimen menunjukkan adanya perbedaan susunan. Struktur mikro didominasi oleh ferit dan perlit. Dengan menggunakan elektroda E7018, menghasilkan perlit yang lebih halus. Berdasarkan uji tarik, terdapat perbedaaan yang signifikan. Pada spesimen E 6013 memiliki kekuatan tarik rata-rata sebesar 275,7 kN/mm2, sedangan E 7018 memiliki kekuatan rata-rata sebesar $419,5 \mathrm{kN} / \mathrm{mm} 2$. Sehingga bisa disimpulkan, jenis elektroda mempengaruhi kekuatan tarik pengelasan baja AISI 1045 dan SS202
\end{abstract}

Kata kunci: aisi 1045; elektroda; kekuatan tarik; SS202; struktur mikro.

\section{Abstract}

Dissimilar metal welding is a welding process carried out on two different types of metals. Dissimilar metal welding is widely used in various industries, such as power plants, the transportation industry, civil construction, and others. Steel is a material widely used for construction. Many applications are joining with other metals. The joining is carried out by welding. In combining two different metals, problems that often arise in welding include melting point differences, expansion coefficients, physical 
and mechanical properties. Therefore, the selection of the right welding electrodes will produce a good connection. This study aims to determine the effect of electrodes on AISI 1045 and SS202 on the microstructure and tensile strength. Electrodes type E 6013 and E 7018 is used in this work. SMAW machine welding is used to joining. The microstructure is characterized using an optical microscope. Mechanical strength is tested using a tensile testing machine. The results of observations of microstructure in each specimen showed differences in the composition. The microstructure is dominated by ferrite and pearlite. By using E7018 electrodes, it produces finer pearlite. Based on tensile tests, there are significant differences. The E 6013 specimen has an average tensile strength of $275.7 \mathrm{kN} / \mathrm{mm} 2$, whereas $E 7018$ has an average strength of $419.5 \mathrm{kN} / \mathrm{mm} 2$. So it can be concluded, the type of electrode affects the tensile strength of AISI 1045 and SS202 steel welding.

Keywords : aisi 10451; electrode; tensile strength; SS202; microstructure

\section{PENDAHULUAN}

Akhir-akhir ini perkembangan teknologi di sektor kontruksi saat ini sangat meningkat, khususnya di bidang kontruksi yang melibatkan logam. Untuk menghasilkan kontruksi yang berkualitas maka diperlukan suatu teknologi untuk menggabungkan logam yaitu menggunakan teknologi pengelasan. Selain untuk menyambung, las juga digunakan untuk menambal lubang maupun menambah tebal permukaan jenis (Nasrul dkk, 2016). Sambungan beda jenis merupakan metode penyambungan yang dilakukan pada dua jenis material logam yang berbeda. Pengelasan logam berbeda (dissimilar metal welding) adalah teknologi las yang dikembangkan akibat dari kebutuhan akan penyambungan logam yang memiliki jenis yang berbeda (Sugestian, 2019). Untuk menyesuaikan dan memenuhi kebutuhan teknologi, pengelasan beda jenis banyak dipakai diberbagai bidang industri, misalnya industri pembangkit listrik, industri transportasi, kontruksi sipil, dan lain-lain (Pareke, 2014). logam yang memiliki ciri perbedaan fisik, mekanik, thermal dan metalurgi sehingga memiliki karakter sambungan berbeda. Pengontrolan struktur mikro maupun sifat mekanik pada daerah las umumnya pada saat terjadi root pass lebih penting karena mengakibatkan fasa campuran ferit, dan martensit terbentuk (Sudargo dan Baroto, 2017).

Stainless steel 202 adalah logam yang memiliki sifat tidak mudah berkarat karena memiliki kandungan kadar besi $(\mathrm{Fe})=72,6 \%$, $\operatorname{khrom}(\mathrm{Cr})=17,6 \%$, mangan $(\mathrm{Mn})=10,0 \%$ dan nikel $(\mathrm{Ni})=4,01 \%$. Berdasarkan kandungannya material jenis ini tidak mudah berpengaruh terhadap korosi yang cukup tinggi logam jenis ini biasanya sering dipakai dalam industri penerbangan maupun industri perkapalan (Trianto, 2016). Baja AISI 1045 memiliki komposisi kimia antara lain $(0,4-0,45 \% \mathrm{C}),(0,1-0,3 \% \mathrm{Si}),(0,60-0,90 \% \mathrm{Mn}),(0,025 \% \mathrm{Mo})$, $(0,04 \mathrm{max} \% \mathrm{P}),(0,05 \mathrm{max} \% \mathrm{~S})$ (Pramono, 2011).Dalam penggabungan dua logam yang berbeda permasalahan yang sering timbul dalam pengelasan antara lain perbedaan titik lebur, koefisien muai, sifat fisis dan mekanis dari logam tersebut sehingga sebelum melakukan pengelasan perlu diketahui kandungan unsur material yang akan dilas. Menurut Arifin dkk (2017) penggunaan arus dan elektroda yang bervariasi saat pengelasan berpengaruh pada sifat mekanik dan fisik hasil pengelasan.

Oleh karena itu diperlukan suatu upaya untuk meneiliti pengaruh elektroda terhadap pengelasan logam beda jenis AISI 1045 dan SS 202 menggunakan las SMAW, hasil sambungan akan di uji kekuatan tariknya dan diamati struktur mikronya, data hasil pengujian dan pengamatan akan dibahas. 


\section{METODE}

Material yang digunakan dalam penelitian ini adalah baja AISI 1045 dan SS 202, dengan ketebalan $5 \mathrm{~mm}$. Komposisi kimia dari material tersebut ditunjukan pada Tabel 1 dan Tabel 2.

Tabel 1. Komposisi kimia Baja AISI 1045

\begin{tabular}{cccccc}
\hline Kode & C \% & Si \% & Mn \% & P \% & S \% \\
\hline Aisi 1045 & $0,4-0,45$ & $0,60-0,90$ & 0,025 & 0,04 max & 0,05 max \\
\hline
\end{tabular}

Tabel 2. Komposisi kimia SS 202

\begin{tabular}{ccccc}
\hline Kode & Fe & Cr & Mn & Ni \\
\hline SS 202 & $72,6 \%$ & $17,6 \%$ & $10,0 \%$ & $4,01 \%$ \\
\hline
\end{tabular}

Mesin las SMAW ini digunakan untuk proses penyambungan pada pengelasan baja AISI 1045 dan SS 202 dengan menggunakan arus tetap yaitu100 A.

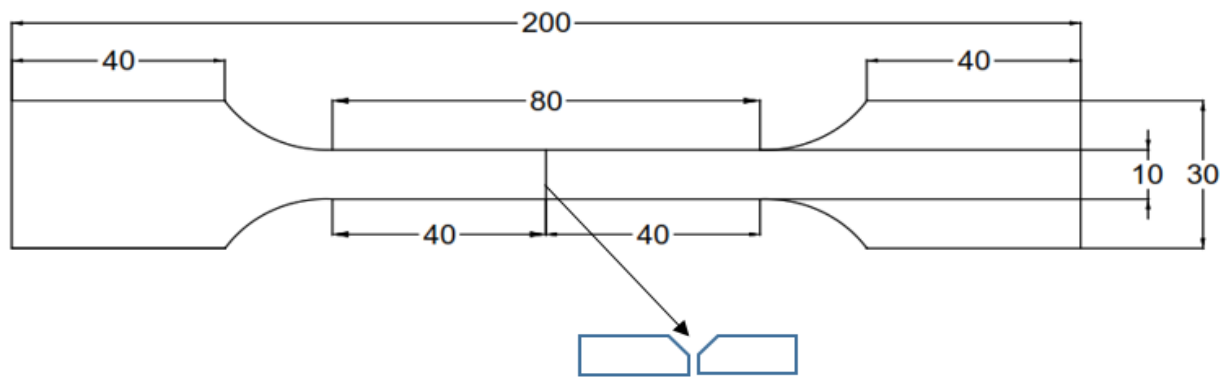

Gambar 1.Sambungan Tumpul pada Las SMAW JIZ Z2 202

Ukuran spesimen menganut pada standart JIZ Z2 202 seperti ditunjukkan pada Gambar 1.

Kekuatan sambungan diuji menggunakan mesin uji universal. Struktur mikro sambungan dikarakterisasi menggunakan mikroskop optik setelah melalui preparasi spesimen. Cairan nital digunakan untuk etsa spesimen.

\section{HASIL DAN PEMBAHASAN}

Hasil uji tarik ditunjukkan pada Tabel 3 dan Tabel 4. Berdasarkan hasil pengujian tarik menunjukkan bahwa dari perbandingan tiap-tiap elektroda mempunyai perbedaan, mulai dari tegangan, regangan dan modulus elastisitas. Pada hasil pengujian dari kedua elektroda yang berbeda menunjukkan bahwa pada tabel 4 dengan elektroda E 7018 memiliki rata-rata tegangan tertinggi yaitu sebesar $419,5 \mathrm{kN} / \mathrm{mm}^{2}$, dengan nilai regangan rata-rata sebesar 0,0003 dan untuk nilai modulus elastisitas tertinggi yaitu pada elektroda E 7018 dengan nilai rata-rata sebesar $988,5 \mathrm{kN} / \mathrm{mm}^{2}$. Sedangkan pada elektroda E 6013 memiliki tegangan ratarata $275,7 \mathrm{kN} / \mathrm{mm}^{2}$., nilai regangan dengan nilai rata-rata sebesar 0,0003 dan untuk nilai modulus elastisitasnya memiliki rata-rata sebesar $689,4 \mathrm{kN} / \mathrm{mm}^{2}$.

Dari hasil yang didapatkan dalam pengujian menunjukkan bahwa elektroda E6013 mempunyai nilai rata-rata sebesar $275,7 \mathrm{kN} / \mathrm{mm} 2$, sedangkan kekuatan tarik tertinggi terdapat pada elektroda E 7018 dengan nilai rata-rata sebesar 419,5 kN/mm2. Setelah dilakukan proses penelitian dan pengujian pada setiap elektroda pada las SMAW terbukti adanya pengaruh terhadap sifat-sifat mekanik, hal ini ditunjukkan dengan adanya nilai yang 
signifikan pada elektroda E 7018 dengan nilai rata-rata kekuatan tariknya sebesar 419,5 $\mathrm{kN} / \mathrm{mm} 2$. Elektoda jenis E 7018 memiliki kekuatan tarik relative lebih tinggi karena kandungan fluks yang terdapat pada tipe elektroda E 7018 berupa serbuk besi yang juga terdapat pula kandungan hidrogen rendah di dalamnya, dimana $\mathrm{H}^{2}$ merupakan reduktor untuk menghilangkan oksigen dari oksida logam sedangkan ketangguhan logam las turun apabila kadar oksigen di dalamnya naik (huda dkk, 2018).

Tabel 3. Data Uji Tarik Spesimen Uji Menggunakan Elektroda E 6013

\begin{tabular}{|c|c|c|c|c|c|c|}
\hline $\begin{array}{c}\mathbf{L}_{0} \\
(\mathbf{m m})\end{array}$ & $\begin{array}{c}\mathbf{F} \\
(\mathbf{k N})\end{array}$ & $\begin{array}{c}\mathbf{L}_{\mathbf{i}} \\
(\mathbf{m m})\end{array}$ & $\begin{array}{c}\mathbf{A}_{\mathbf{i}} \\
\left(\mathbf{m m}^{2}\right)\end{array}$ & $\begin{array}{l}\text { Tegangan } \\
\left(\mathbf{k N} / \mathbf{m m}^{2}\right)\end{array}$ & Regangan & $\begin{array}{c}\text { M. } \\
\text { Elastisitas } \\
\left(\mathrm{kN} / \mathbf{m m}^{2}\right)\end{array}$ \\
\hline 80 & 15980.6 & 80,02 & 50 & 319,6 & 0,0004 & 799,0 \\
\hline 80 & 15062.1 & 80,03 & 50 & 301,2 & 0,0003 & 753,1 \\
\hline 80 & 10126.2 & 80,03 & 50 & 202,5 & 0,0003 & 506,3 \\
\hline 80 & 12686.1 & 80,02 & 50 & 253,7 & 0.0003 & 634,3 \\
\hline 80 & 15087.4 & 80,03 & 50 & 301,7 & 0,0003 & 754,3 \\
\hline \multicolumn{4}{|c|}{ Rata-rata } & 275,7 & 0,0003 & 689,4 \\
\hline
\end{tabular}

Tabel 4. Data Uji Tarik Spesimen Uji Menggunakan Elektroda E 7018

\begin{tabular}{|c|c|c|c|c|c|c|}
\hline $\begin{array}{c}\mathbf{L}_{0} \\
(\mathbf{m m})\end{array}$ & $\begin{array}{c}\mathbf{F} \\
(\mathbf{k N})\end{array}$ & $\begin{array}{c}\mathbf{L}_{\mathbf{i}} \\
(\mathbf{m m})\end{array}$ & $\begin{array}{c}\mathbf{A}_{\mathbf{i}} \\
\left(\mathbf{m m}^{2}\right)\end{array}$ & $\begin{array}{l}\text { Tegangan } \\
\left(\mathrm{kN} / \mathrm{mm}^{2}\right)\end{array}$ & Regangan & $\begin{array}{c}\text { M. } \\
\text { Elastisitas } \\
\left(\mathbf{k N} / \mathbf{m m}^{2}\right)\end{array}$ \\
\hline 80 & 19564.3 & 80,03 & 50 & 391,2 & 0,0003 & 978,2 \\
\hline 80 & 19958.2 & 80,04 & 50 & 399,1 & 0,0003 & 997,9 \\
\hline 80 & 19268.9 & 80,03 & 50 & 385,3 & 0,0003 & 963,4 \\
\hline 80 & 20542.1 & 80,04 & 50 & 511,2 & 0,0004 & 1027,1 \\
\hline 80 & 19.5186 & 80,04 & 50 & 410,8 & 0,0004 & 975,9 \\
\hline \multicolumn{4}{|c|}{ Rata-rata } & 419,5 & 0,0003 & 988,5 \\
\hline
\end{tabular}

Dari hasil yang didapatkan dalam pengujian menunjukkan bahwa elektroda E6013 mempunyai nilai rata-rata sebesar $275,7 \mathrm{kN} / \mathrm{mm} 2$, sedangkan kekuatan tarik tertinggi terdapat pada elektroda E 7018 dengan nilai rata-rata sebesar 419,5 kN/mm2. Setelah dilakukan proses penelitian dan pengujian pada setiap elektroda pada las SMAW terbukti adanya pengaruh terhadap sifat-sifat mekanik, hal ini ditunjukkan dengan adanya nilai yang signifikan pada elektroda E 7018 dengan nilai rata-rata kekuatan tariknya sebesar 419,5 $\mathrm{kN} / \mathrm{mm} 2$.Elektoda jenis E 7018 memiliki kekuatan tarik relative lebih tinggi karena kandungan fluks yang terdapat pada tipe elektroda E7018 berupa serbuk besi yang juga terdapat pula kandungan hidrogen rendah di dalamnya, dimana $\mathrm{H}^{2}$ merupakan reduktor untuk menghilangkan oksigen dari oksida logam sedangkan ketangguhan logam las turun apabila kadar oksigen di dalamnya naik (Huda dkk, 2018).

Sedangkan nilai rata-rata kekuatan tarik terendah terdapat pada elektroda jenis E 6013 dapat disimpulkan cacat ini besar kemungkinan dikarenakan elektroda jenis ini termasuk 
jenis low penetration. Hasil dari pengujian yang sudah dilakukan, menunjukkan bahwa pengujian ini rata-rata patahan spesimen terletak pada daerah sambungan las, yang terbukti bahwa daerah las tersebut merupakan daerah yang secara langsung terkena unsur-unsur panas yang paling maksimal saat proses pengelasan berlangsung (Gutama, 2000).

Berubahnya harga kekuatan tarik hasil pengelasan baja karbon sedang dengan baja tahan karat dapat dipengaruhi oleh keadaan, cara dan prosedur pengelasan, maupun pemilihan juru las yang kurang tepat di samping itu juga tergantung pada tempat pengambilan batang uji (Tarkono dkk, 2013).

Menurut Veranika dkk (2019), dalam penelitianya menyatakan kandungan dalam jenis Elektroda E 7018 adalah selaput serbuk besi yang berguna untuk meningkatkan efisiensi pengelasan, sertarendah hidrogen sehingga mempengaruhi proses pendinginan logam las, sehingga pendinginan akan lebih cepat sehingga logam las akan menjadi lebih keras, kuat untuk penyambungannya. Sedangkan kandungan dalam jenis elektroda E 6013 adalah natrium titania tinggi, keuntungannya daerah lasan terbebas dari penyusupan-penyusupan terak dan dari pengaruh oksidasi, dipakai khusus untuk mengelas baja lunak, terutama untuk pengelasan plat-plat tipis, tidak bisa untuk mengelas plat yang tebal.

\section{Pengamatan Struktur Mikro}

Pengamatan struktur mikro ini menggunakan alat mikroskop optik yang dilakukan pada kedua spesimen dengan variasi jenis elektroda yang berbeda hal ini bertujuan untuk mengetahui bentuk dan susunan pada tiga bagian yaitu: daerah las, daerah HAZ dan logam induk. Hasil pada pengamatan struktur mikro menggunakan elektroda E6013 bisa dilihat pada Gambar 2 dan dan menggunakan elektroda E7018 ditunjukkan pada Gambar 3 di bawah ini:
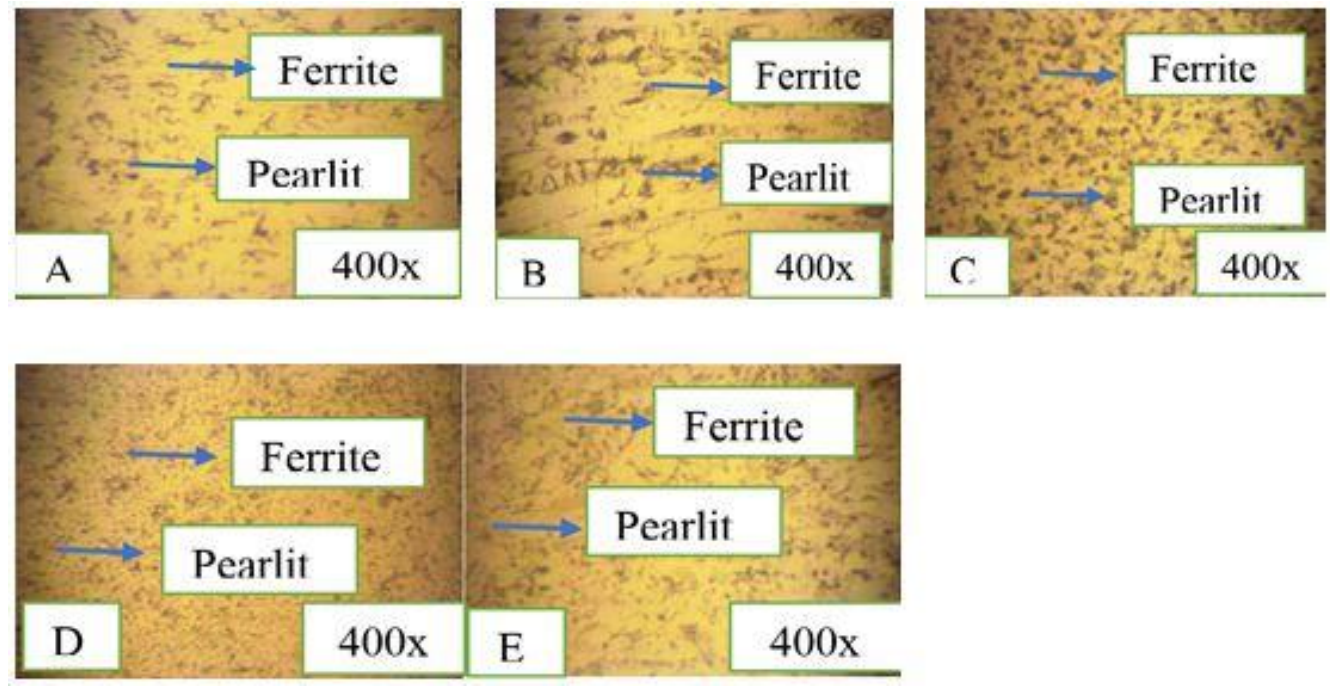

Gambar 2. Hasil Struktur Mikro Elektroda E6013

(A)Logam Induk Baja, (B) Logam induk SS, (C) LAZ, (D) HAZ Baja,

(E) HAZ SS

Dilihat dari hasil foto struktur mikro yang diperoleh, menunjukkan terjadinya perbedaan dan perubahan struktur mikro. Bentuk ukuran struktur yang berbeda ini diakibatkan karena perbedaan panas (kekuatan arus yang berbeda) dan transformasi fasa terutama pada daerah fusi yaitu batas antara daerah HAZ dan logam las, sehingga mengakibatkan kekuatan lasnya berbeda-beda. 
Dilihat dari Gambar 2 dan Gambar 3 bagian (A), (B) logam induk memiliki struktur yang didominasi pearlite dan ferrite yang merupakan struktur mikro dari baja, Struktur pearlite ditunjukkan dengan struktur yang berwarna kelabu dan gelap, sedangkan unsur ferrite ditunjukkan dengan warna yang lebih terang. Struktur mikro dengan elektroda E7018 memiliki unsur pearlite yang lebih banyak, rapat dan dominan. Hal ini sesuai dengan kekuatan tarik, bahwa elektroda E7018 memiliki kekuatan rata-rata sebesar 419,5 kN/mm2 , dan ini membuktikan bahwa elektroda E7018 memiliki kekuatan tarik jauh lebih besar dibandingkan dengan elektroda E 6013, Hal ini bisa terjadi karena unsur pearlite juga tersusun oleh lapisan-lapisan halus dan memiliki sifat yang lebih kuat dan keras dari pada ferrite (Wijoyo \& Aji, 2015).

Dilihat dari Gambar 2 dan Gambar 3 bagian (D), (E) HAZ, struktur mikro menjadi rusak dari logam induknya, yaitu struktur pearlite dan ferrite menjadi hancur menjadi butiran bertambah kecil. Struktur mikro pada daerah HAZ dengan elektroda E 7018 mempunyai unsur paerlite yang lebih banyak dibandingkan dengan elektroda E 6013, dengan adanya itu maka elektroda E7018 memiliki kekuatan tarik yang lebih besar. Selain itu bagian yang paling terpengaruh oleh siklus thermal adalah daerah las (Sudargo dan Baroto, 2017)
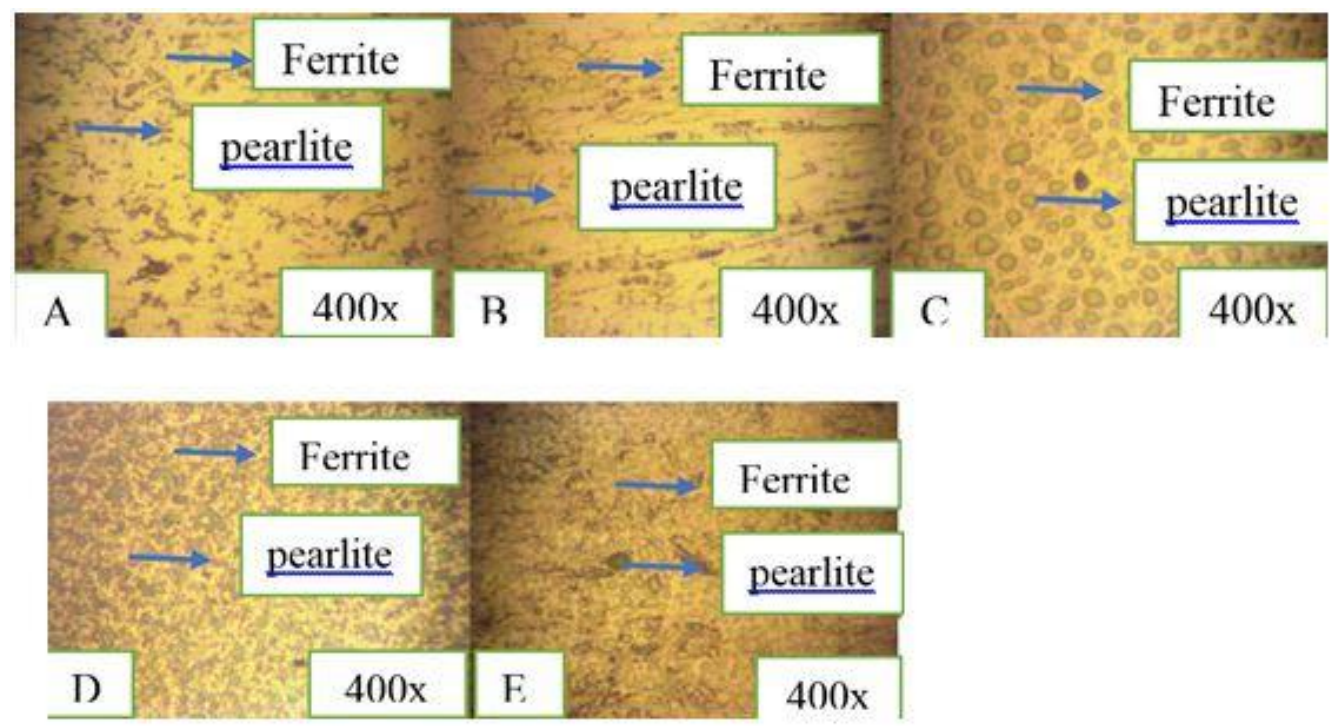

Gambar 3. Hasil Struktur Mikro Elektroda E7018

(A) Logam Induk Baja, (B) Logam induk SS, (C) LAZ, (D) HAZ Baja,

(E) HAZ SS

Disaat proses pengelasan berlangsung pada daerah las terjadi pencairan dan pendinginan secara lambat. Dilihat dari Gambar 2 dan Gambar 3 bagian (C) daerah las ini, struktur mikronya lebih besar dan lebih renggang yang didominasi ferrite dan pearlite yang semakin berkurang. Dari kedua spesimen dengan variasi jenis elektroda E 6013 dan E 7018 menunjukkan bahwa elektroda E7018 masih mendominasi unsur pearlite, sehingga elektroda E 7018 memiliki kekuatan tarik yang lebih besar dibandingan dengan kuat E 6013. Hal ini dimungkinkan disebabkan karena beberapa factor seperti ukuran gap yang yang terlalu kecil, heat input yang rendah atau karena factor penggunaan jenis elektroda. Akan tetapi dapat disimpulkan cacat ini besar kemungkinan dikarenakan factor penggunaan jenis elektroda E 6013 dimana elektroda jenis ini termasuk jenis low penetration (Yakub, 2013).

Jumlah presentase kandungan struktur perlit lebih sedikit dibandingkan dengan presentanse ferit yang lebih banyak disebabkan oleh unsur karbon yang terperangkap oleh 
daerah lasan pada waktu didinginkan dengan udara. Pertumbuhan butir yang berlebihan dapat menyebabkan berkurangnya nilai kekuatan dan meningkatkan inisiasi dan pertumbuhan retak pada logam. Hal tersebut dapat mempengaruhi ketangguhan retak yang mungkin timbul karena siklus pemanasan dan pendinginan (Kurniawan, 2019).

Berubahnya nilai kekuatan tarik dari hasil pengelasan tersebut terjadi karena adanya perubahan perbedaan struktur mikro yang terjadi saat proses pengelasan berlangsung, Semakin banyak dan rapat posisi unsur (perlite) maka menunjukkan kekuatan tarik semakin besar dan begitu pula sebaliknya. Ferrite merupakan larutan padat dari atom murni yang mempunyai sel-sel kubus dan memiliki sifat yang lebih lunak dan liat, sedangkan pearlite juga tersusun oleh lapisan-lapisan halus dan memiliki sifat yang lebih kuat dan keras dari pada ferrite. Hal ini bisa terjadi karena pada saat proses pengelasan berlansung terjadi perbedaan masukan panas (kuat arus) pada daerah las. Masukan panas (heat input) ini, nilainya berbanding lurus dengan arus dan tegangan yang digunakan, serta berbanding terbalik dengan kecepatan pengelasan. Bila menggunakan heat input yang rendah maka mengharuskan kecepatan pengelasan yang relatif pelan, sehingga energi panas banyak yang menyebar kebagian logam, sehingga makin banyak pula daerah yang mengalami perubahan struktur kristal dan begitu pula sebaliknya (Budiarsa, 2008).

Menurut Suhermana dkk (2018), ada beberapa faktor yang mempengaruhi perkembangan mikrostrukur daerah las yaitu komposisi logam las, laju pendinginan dari temperatur $800-500^{\circ} \mathrm{C}$, kandungan oksigen dalam logam las dan ukuran butir austenit

\section{KESIMPULAN DAN SARAN}

Berdasarkan penelitian yang sudah dilakukan maka hasilnya dapat disimpulkan sebagai berikut:

a. Struktur mikro pada masing-masing daerah pengamatan, didominasi oleh fereit dan perlit. Semakin banyak dan rapat unsur perlit maka kekuatan tarik yang dihasilkan akan semakin besar.

b. Hasil uji tarik menunjukkan bahwa masing-masing elektroda memiliki perbedaan kekuatan. Kekuatan tarik menggunaka elektroda E6013 rata-rata mencapai 275,7 $\mathrm{kN} / \mathrm{mm}^{2}$, sedangkan menggunakan elektroda E7018 mengalami kenaikan dengan nilai sebesar $419,5 \mathrm{kN} / \mathrm{mm}^{2}$.

\section{DAFTAR RUJUKAN}

Arifin J, Purwanto H, Syafa'at I. (2017). Pengaruh jenis elektroda terhadap sifat mekanik hasil pengelasan smaw baja ASTM A36. Momentum, 13(1), 27-31.

Budiarsa, I. N. (2008). Pengaruh besar arus pengelasan dan kecepatan volume alir gas pada proses las GMAW terhadap ketangguhan aluminium 5083. CAKRAM, 2(2), 112-116.

Gutama H.K, Wulandari D. (2000). Pengaruh Arus Pengelasan Dan Jenis Elektroda Terhadap Kekuatan Tarik Pada Steel 42. Jurnal Teknik Mesin Fakultas Teknik Unesa, (1), 1-5.

Huda M, Respati B.S.M, Purwanto H. (2018). Pengelasan plat kapal dengan variasi jenis elektroda dan media pendingin. Momentum, (14), 50-56.

Kurniawan. Dwi. (2019). Analisa pengaruh variasi elekroda pengelasan smaw sambungan logam baja jis $g 3131$ sphc dengan baja aisi ss 201 terhadap sifat mekanis. [Skripsi] Institut Teknologi Nasional Malang

Nasrul,Y. L.M., H. Qolik S.A, (2016). Pengaruh variasi arus las smaw terhadap kekerasan dan 
kekuatan tarik sambungan dissimilar stainless steel 304 dan st 37. Jurnal Teknik Mesin, Universitas Negeri Malang (1), 1-12.

Pareke S, Muchsin A.H, Leonard J. (2014). Pengaruh pengelasan logam berbeda (AISI 1045) dengan (AISI 316L) erhadap sifat mekanis dan struktur mikro. Sains dan teknologi, 3(2), 191-198.

Pramono, A. (2011). Karakteristik mekanik proses hardening baja AISI 1045 Media Quenching Untuk Aplikasi Sprochet Rantai. Cakram 5(1), 32-38.

Sugestian, M Rizsaldy. (2019). Analisa kekuatan sambungan las smaw horizontal down hand pada plate baja jis 3131sphc dan stainless steel 201 dengan aplikasi piles transfer di mesin thermoforming (stacking unit). [Skripsi] Institut Teknologi Nasional Malang.

Suhermana , R. M. Ambaritab , R. K. Simangunsongc , P.J. Simanjuntak (2018). Pengaruh jenis elektroda E6013 pada pengelasan SMAW terhadap sifat fisis dan mekanis baja SA106 grade B. Prosiding Seminar Nasional Era Industri (SNEI) UPMI Medan, 50-54

Tarkono, Zulhanif, Trisulohadi Ben Fikma (2013). Pengaruh kedalaman alur back chipping pada pengelasan listrik SMAW baja karbon sedang AISI 1045 terhadap uji kekuatan tarik. Fema, 1, 18-27.

Trianto A. (2016). Penelitian stainless steel 202 terhadap pengaruh pengelasan gas tungsten arc welding(GTAW) untuk variasi arus 50 A, 100 A, Dan 160 A dengan uji komposisi kimia, uji struktur mikro, uji kekerasan dan uji impact. [Skripsi]. Jurusan Teknik Mesin, Fakultas Teknik UMS.

Veranika R.M, Fauzie M.A, Ali H, Solihin M, (2019). Studi pengaruh variasi elektroda e 6013 dan e 7018 terdahap kekuatan tarik dan kekerasan pada bahan baja karbon rendah. Desiminasi Teknologi, 7.

Wijoyo, \& Aji, B. K. (2015). Kajian kekerasan dan struktur mikro sambungan las GMAW baja karbon tinggi dengan variasi masukan arus listrik. SIMETRIS, 6(2), 243-248.

Yakub Y, Nofri M, (2018). Variasi arus listrik terhadap sifat mekanik mikro sambungan las baja tahan karat aisi 304. E-Jurnal WIDYA Eksakta, 1(I).7-11 